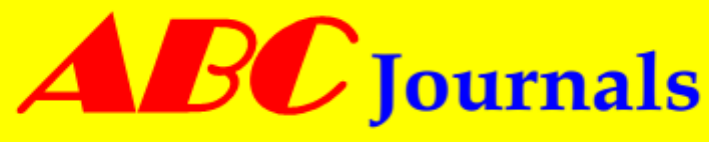

A new domain in research publishing

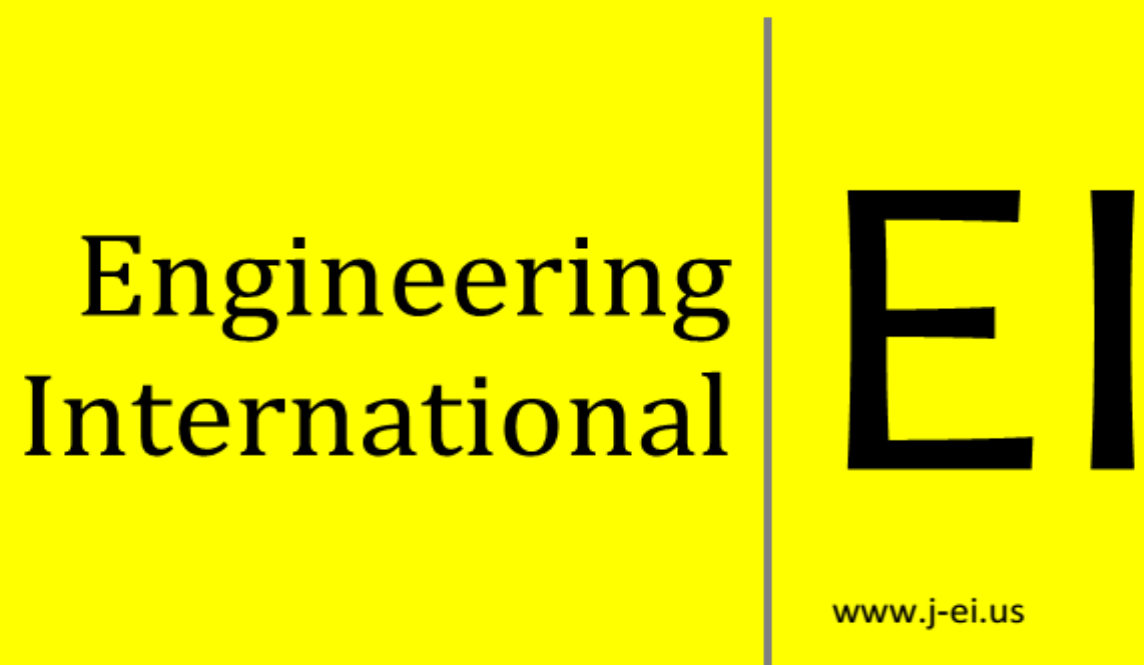

Asian Business Consortium 


\title{
Development of a Small Scale Concentrating Parabolic trough Solar Collector for Drying Purposes
}

\author{
Muhammad Aamir khan'; M.Rahman²; M. Hanif ${ }^{3}$; \\ Muhammad Israr ${ }^{4}$ \& S. Fahad Shah ${ }^{5}$
}

1,2\&3 Department of Agricultural Mechanization, Faculty of Crop Production Sciences, The University of Agriculture, Peshawar, Pakistan

${ }^{4 \& 5}$ Department of Rural Development, Institute of Development Sciences, The University of Agriculture, Peshawar, Pakistan

\begin{abstract}
A high performance solar collector was developed to modify agricultural building environment such as dairy, poultry farm buildings and greenhouses. Moreover it should be efficiently utilized as a solar dryer for drying various agricultural products and by products. The materials used include steel sheet with high performance of reflecting light, absorber tube, and angle iron and fully insulated drying chamber. A CPTSC was a tilted at 340south (Equivalent to the latitude of Peshawar) Pakistan. A CPTSC a total reflecting surface area was $2.9 \mathrm{~m} 2$ respectively. The absorber tube having a surface of $0.376 \mathrm{~m} 2$ was fixed in front of the reflector at the distance equal to the focal length. The total volume of drying chamber was $0.3135 \mathrm{~m} 3$. An experiment was conducted to enhance the efficiency of the CPTSC and two air mass flow rate treatments were tested with normal and convective mass air flow rate, $0.6 \mathrm{~kg}$. Min-1 and $1.72 \mathrm{~kg}$. Min-1 under the average temperature of the month (January, February and March, 2012). Moreover, the process was replicated three times under the completely randomized design. The result showed that both air mass flow rate and average temperature of the month significantly effected the efficiency of a concentrating parabolic trough solar collector. The new model of a CPTSC increased the efficiency from 8 to $25 \%$ with increase in both air mass flow rates and average temperature of the months. Therefore it is concluded that the solar collector efficiency increased with increasing air mass flow rate.
\end{abstract}

Key word: Solar Energy, Solar Collector, Solar Drier and Collector Efficiency.

\section{INTRODUCTION}

Solar drying one of the oldest applications of solar energy it was used for different purposes. The first installation for drying by solar energy was found in southern France and is dated at about 800 B.C. It was a stone paved surface and used for drying of crops (Matthew 2001). The radiation heat loss to the air and conductive heat loss through the 
insulation plays a dominant role in the light-heat conversion. The radiation heat loss is dependent on the cavity wall temperature, the shape factors and emissivity absorptive of the receiver wall temperature and the isothermal boundary condition, the effect of thermal radiation on the natural convection can be neglected and conduction and radiation heat losses can be readily determined. But the determination of convection heat loss is rather difficult due to the complexity of the temperature and velocity fields in and around the receiver (Shuang 2011). Pakistan receiver solar radiation falls all over the year with great intensity. The intensity flux is very high and it is studied that daily weekly and monthly solar intensity at Karachi and other places of Pakistan have very much bright prospects of solar radiation. In Pakistan it is about $20 \mathrm{MJ} \mathrm{Min}^{-1}$ of solar insolation with an annual total of $7000 \mathrm{MJ}$. Min ${ }^{-1}$. Accept monsoon months the solar irradiance is very encouraging (Ahmed 2011). Non-Conventional energy resources are renewable energy resources. Among renewable resource, solar energy has bright prospects for utilization; it is about $1 \mathrm{Cal} . \mathrm{cm}^{-2}$. $\mathrm{min}^{-1}$. Energy is falling on the total area of the country in one min which can be fulfilling the total energy requirement of the country for one day. There is a need to converge it (Dikbasan, 2007). The technical performance of a solar dryer, Its efficiency in natural $\left(0.015 \mathrm{~kg}\right.$. s ${ }^{-1}$ that the efficiency at normal air mass flow rate $14.5 \%$ which increased to $40 \%$ at convective air mass flow rate chili and beef were dried in the solar dryer and chilies took 12 hours and beef took 24 hours for drying (Fuller 2005). The products of agriculture are hygroscopic and drying rate is a mean importance of the product there are two different phase I, the initial constant rate of drying period during which surface is saturated with vapor and the products evaporate takes place always from the surface and to enough water to evaporate. Phase II, the falling rate period, Moisture diffusion is controlled by interior fluid movement while surface becomes continuously depleted in water, secondly the following period, where the moisture content nonstop to reduce while waiting for stability is achieved and the product drying step (Belessiotis 2010).

\section{Objectives}

The specific objectives of this study were:

- To develop a concentrating type parabolic trough solar collector.

- To study the efficiency of the concentrating parabolic trough solar collector.

- To study the performance of the parabolic trough solar collector for drying fruits.

\section{Materials ANd Methods}

\section{Site Selection}

The CPTSC and the connected drying box was installed on the roof of Agricultural Mechanization building The University of Agriculture, Peshawar, Pakistan this site was selected because of unobstructed sunshine.

\section{a. Parabolic Trough}

The solar collector was composed of CPTSC. The reflector was made of a shiny sheet 1.21 $\mathrm{m}$ wide and $2.4 \mathrm{~m}$ long and its thickness was $0.02 \mathrm{~m}$. The reflector steel sheet collector $(2.9$ $\mathrm{m}^{2}$ ). The materials used were easily available in the market. The shiny sheet supported and tilted with the help of a frame made up of angled iron arms. 


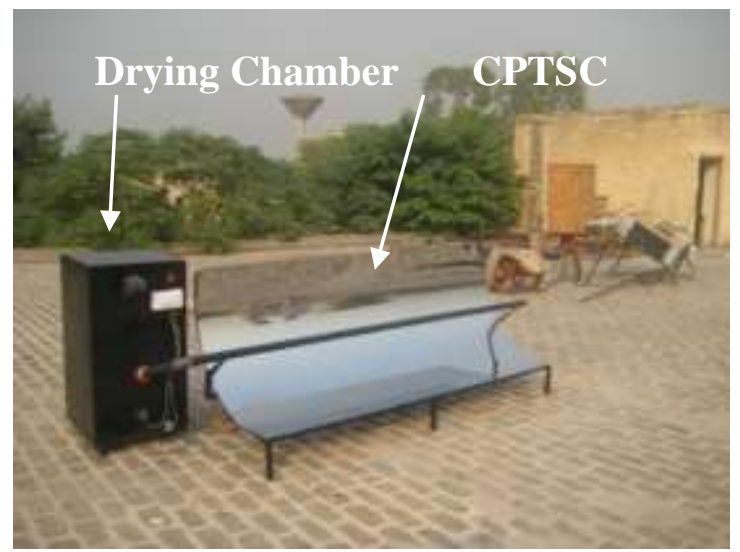

Figure 1: Concentrating Parabolic Trough Solar Collector.

i. Focal line of a Concentrating Parabolic Trough.

The focal point of a concentrating parabolic trough was calculated using the following equation developed by (Balbir, 2009).

$f=\frac{w 2}{16 d}$

Where $\mathrm{f}$ is the focal point, $\mathrm{w}$ is the width of the parabolic trough, $1.21 \mathrm{~m}$ and $\mathrm{d}$ is the depth $0.51 \mathrm{~m}$ of a concentrating parabolic trough solar collector.

\section{ii. Cross Sectional Area of the Trough}

The surface area of the reflecting trough was calculated using the formula developed by [13].

$\mathrm{A}_{\mathrm{rt}}=\mathrm{D}_{\mathrm{rt}} \times \mathrm{L}_{\mathrm{rt}}$

Where $D_{\mathrm{rt}}$ Aperture of the reflecting parabolic trough which is $1.21 \mathrm{~m}$ and $\mathrm{L}_{\mathrm{rt}}$ is the Length of reflects trough which is $2.4 \mathrm{~m}$. Putting these values in equation 3 we get a total of $2.9 \mathrm{~m}^{2}$ surface area of the parabolic trough.

\section{iii. Absorber}

The absorber consists of a black painted steel pipe having $0.05 \mathrm{~m}$ diameter. The length of absorber was $2.4 \mathrm{~m}$ long. The pipe received air from outside environment which was heated in the absorber and then this hot air was diverted to the drying box.

iv. Calculating Absorber Area

As the absorber was composed of a steel pipe its surface area was calculated using the formula developed by (Yadav 2011).

$\mathrm{A}_{\mathrm{ab}}=2 \pi \mathrm{rab} \mathrm{Lab}$

Where $\mathrm{rab}_{\mathrm{ab}}$ radius of the absorber which is $0.025 \mathrm{~m}$ and $\mathrm{Lab}_{\mathrm{ab}}$ is the length of the absorber which is $2.4 \mathrm{~m}$. Putting these values in the equation we get the surface area of the absorber which is $0.382 \mathrm{~m}^{2}$.

\section{b. Drying Box}

The drying box was a steel box fully insulated on the inside with the help of polystyrene foam. The box was $1 \mathrm{~m}$ high and $0.55 \mathrm{~m}$ wide and $0.57 \mathrm{~m}$ long. An exhaust fan having a diameter of 0.05 meters was installed on the outlet duct. It sucked the hot air from the absorber in the drying box. The total volume of the drying box was $0.3135 \mathrm{~m}^{3}$. There was an outlet fixed at the top of the drying box having a diameter of $0.05 \mathrm{~m}$ 


\section{Solar Radiation Data}

The solar radiation data were recorded with the Mechanical Pyranometer. This device gave a data from a chart. This chart reading was multiplied with the Mechanical Pyranometer constant to get the radiation data. 0.88 is the constant value of solar intensity this constant value multiplies with chart value to give the solar intensity data with cal.cm ${ }^{-}$ ${ }^{2} \cdot \mathrm{min}^{-1} \mathrm{Now}$ this value to convert into standard unit we multiplied a constant value (418) to the data to convert it to $\left(\mathrm{kJ} \cdot \mathrm{m}^{-2} \cdot \mathrm{hr}^{-1}\right)$. The solar radiation data were calculated using the formula below developed by (Christian).

$\mathrm{I}_{\mathrm{s}}=0.88 \times \mathrm{V}_{\mathrm{c}}$

Where $\mathrm{I}_{\mathrm{s}}$ incident solar Radiation and $\mathrm{V}_{\mathrm{c}}$ is the chart value of the Pyranometer. For example on $12^{\text {th }}$ January, Year maximum chart value of solar irradiance recorded by the pyranometer was $0.9 \mathrm{cal} . \mathrm{cm}^{-2} \cdot \mathrm{min}^{-1}$. Putting this value in equation 2 we get $0.79 \mathrm{cal} . \mathrm{cm}^{-}$ ${ }^{2} \cdot \mathrm{min}^{-1}$ which is $330.22 \mathrm{~kJ} \cdot \mathrm{m}^{-2} \cdot \mathrm{hr}^{-1}$ when converted to SI units.

\section{Performance of the Concentrating Parabolic Trough Solar Collector}

Performance in terms of efficiency and drying rate was evaluated in the months of January to March, 2012.

\section{Efficiency of the Concentrating Parabolic Trough Solar Collector}

The efficiency of the CPTSC was assessed in the months of January to March, 2012 at two dissimilar air mass flow rates; $\left(0.6\right.$, and $1.72 \mathrm{Kg}$. $\left.\mathrm{min}^{-1}\right)$ were convective air mass flow rates. Temperature data were recorded for the months from January to March, 2012.

It was recorded in percentage (\%). Efficiency was calculated using the following formula developed by (Aswathanarayana).

$\eta=Q_{\circ} / Q_{i x} 100$

Where $\eta$ efficiency of the collector in (\%), Qo output heat of the collector in $\left(\mathrm{kJ} \cdot \mathrm{min}^{-1}\right), \mathrm{Q}_{\mathrm{i}}$ input heat of the collector in $\left(\mathrm{kJ} \cdot \mathrm{min}^{-1}\right)$. Heat input gain " $\mathrm{Q}_{\mathrm{i}}$ " by the collector is calculated by multiplying half of the absorber area to the radiation intensity plus $90 \%$ of the value half of the Area of absorber to the product of solar radiation intensity recorded by the mechanical Pyranometer. This input heat was calculated using the formula developed by (Aswathanarayana).

$Q_{i}=\left(1 / 2 A_{a b} I_{s}\right)+\left\{\left(1 / 2 A_{a b}+A_{r t}\right) I_{r t}\right\}$

$\mathrm{Q}_{\mathrm{i}}$ heat input of the collector $\left(\mathrm{kj} \cdot \mathrm{min}^{-1}\right), \mathrm{A}_{\mathrm{ab}}$ area of the absorber, $\mathrm{A}_{\mathrm{rt}}$ area of reflecting trough, $\mathrm{Is}_{\mathrm{s}}$ the incident solar radiation intensity and Irt the reflected radiation coming from the trough. The output heat of the collector was calculated by multiplying the flow rate of air, specific heat capacity of the air and the difference between the outlet and inlet temperatures. The output heat was calculated by using the following formula developed by (Radu 2010).

$\mathrm{Q}_{\mathrm{o}}=\mathrm{F} \cdot \mathrm{R}$ air $\times \mathrm{C}_{\text {air }} \times \Delta \mathrm{T}$

Where $Q_{0}$ heat output of the collector $\left(\mathrm{kJ} \cdot \mathrm{min}^{-1}\right)$, F.Rair the air mass flow rate at outlet $\left(\mathrm{kg} \cdot \mathrm{min}^{-1}\right), \mathrm{C}$ air specific heat of air $\left(\mathrm{kJ} \cdot \mathrm{kg}^{-1} .{ }^{\circ} \mathrm{C}^{-1}\right)$ and $\Delta \mathrm{T}$ difference in inlet and outlet temperature $\left({ }^{\circ} \mathrm{C}\right)$. The flow rate was calculated by multiplying the velocity of air at the outlet, Area of outlet duct and air density. The flow rate was converted to $\mathrm{kg} \cdot \mathrm{sec}^{-1}$. To convert it to $\mathrm{kg}$. $\mathrm{min}^{-1}$ then multiplied the value by 60 . The flow rate was calculated by using the following formula developed by (Ehiem 2007).

F.R air $=V_{o} \times D_{\text {air }} \times A_{\circ}$

Where F.R air air flow rate $\left(\mathrm{kg} . \mathrm{min}^{-1}\right), \mathrm{V}_{\text {ovelocity }}$ at outlet in $\left(\mathrm{m}_{\mathrm{sec}} \mathrm{se}^{-1}\right), \mathrm{D}_{\text {air }}$ density of air at outlet in $\left(\mathrm{kg} . \mathrm{cm}^{-3}\right)$ and Ao the outlet ducts cross sectional area in $\left(\mathrm{m}^{2}\right)$ 


\section{Moisture Content}

The moisture content of the fruits and vegetables was measured initially and after each hour of drying. The products were dried to less than $10 \%$ moisture content to minimize mold, insects and bacterial assaults. The moisture content was determined by oven method. The temperature of the oven was fixed $105^{\circ} \mathrm{C}$ for 24 hours. Moisture after each hour in drying was determined by taking the initial mass and mass lost after each hour with the help of an electronic balance. The formula for calculating the moisture lost is developed by (Ahmed).

$$
M_{C}=\frac{W_{i}-W_{f}}{W_{\mathbf{i}}^{*}} \times 100
$$

Where $\mathrm{M}_{\mathrm{c}}$ moisture content of the product in (\%), $\mathrm{W}_{\mathrm{i}}$ initial mass and $\mathrm{W}_{\mathrm{f}}$ final mass of the productsin $(\mathrm{g})$.

\section{Determining Drying Rate of the Products}

Drying rate is defined as the quantity of water evaporated per gram of dry matter per unit area in unit time. Drying rate was determined for these products by using the formula developed by [9].

$D_{r}=\frac{\left(W_{i}-W_{f}\right)}{\left(D_{m} \times A_{p} X D t\right)}$

(10) Where $\mathrm{D}_{\mathrm{r}}$, drying rate of the product in $(\mathrm{g}$ H2O. $\left.\mathrm{g}^{-1} \mathrm{dm} . \mathrm{cm}^{-2} \cdot \mathrm{hr}^{-1}\right), W_{\mathrm{i}}$, initial mass, and $\mathrm{W}_{\mathrm{f}}$, final mass of the product after drying in $(\mathrm{g}), \mathrm{Dm}_{\mathrm{m}}$ dry matter in the product in $(\mathrm{g}), \mathrm{A}_{\mathrm{p}}$, cross sectional area of the product in $\left(\mathrm{cm}^{2}\right)$ and $\mathrm{D}_{\mathrm{t}}$, time of drying (hr).

\section{Relative Humidity (\%) and Temperature $\left({ }^{\circ} \mathrm{C}\right)$ Data of air pumping through Inlet and Outlet Ducts}

The data of Relative humidity and temperature was recorded with the help of digital thermo-hygrometer.

\section{Experimental Design}

In accordance with the objectives of this study, a two factorial Complete Randomized Design was used to determine the effect of different air mass flow rates ( 0.60 and 1.72 $\mathrm{kg} \cdot \mathrm{min}^{-1}$ ) and the average temperatures of the months (January to March 2012) on performance in terms of efficiency of a CPTSC. Software named SPSS version 16.0 was used for statistical analysis.

\section{Results and Discussion}

The performance of a CPTSC using two mass air flow rates has been tested. Temperatures of the atmospheres were inlet, and outlet of the CPTSC. The highest temperature of the absorber tube $\left(140^{\circ} \mathrm{C}\right)$ and drying chamber $\left(60^{\circ} \mathrm{C}\right)$ were recorded with the help of a thermometer. And relative humidity less than $10 \%$ was recorded by mean of digital hygrometer shown in Figure.1. The solar intensity was recorded with the help of pyranometer in the months of January, February and March 2012. 


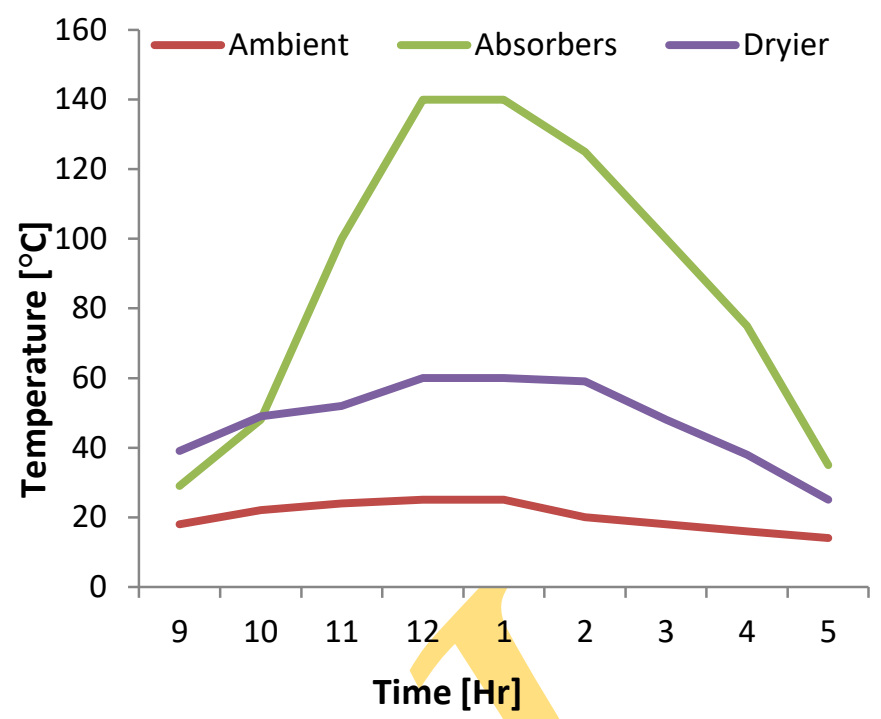

Figure 2. Variations of Solar Radiation Ambient Temperature, Absorber Temperature and Solar Dryer Temperature

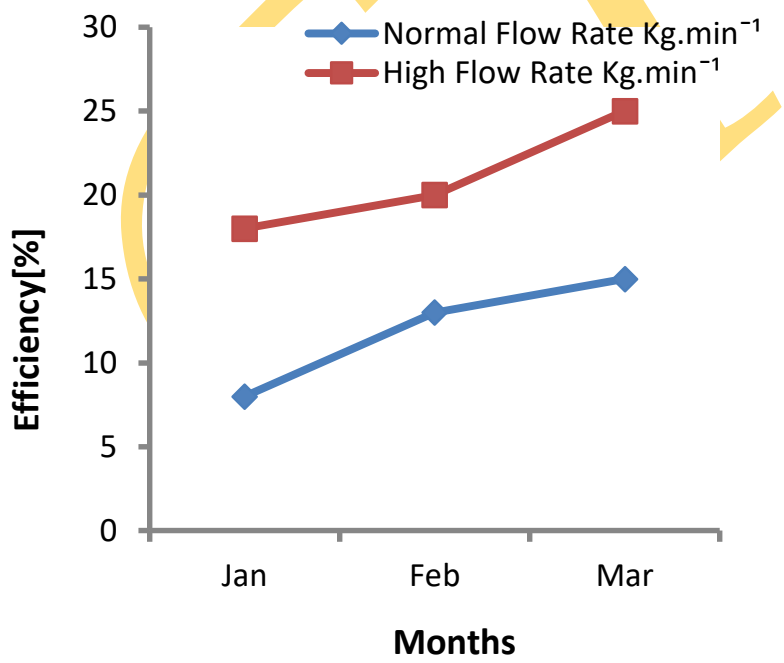

Figure.3 Efficiency of parabolic trough solar collector in the months of January to March The efficiency was found to increase with increase mass flow rate and the difference in temperature $\left(\mathrm{T}_{\mathrm{o}}-\mathrm{T}_{\mathrm{i}}\right)$. The high thermal efficiency $(25 \%)$ at a mass air flow rate of $1.72 \mathrm{Kg}$. $\mathrm{min}^{-1}$, and maximum thermal efficiency $(8 \%)$ at a mass air flow rate $\left(0.6 \mathrm{Kg}\right.$. $\left.\mathrm{min}^{-1}\right)$ were obtained. Agenda through analysis of variance indicated that there were significant difference between the mass air flow rate and average temperature of the months. Show in Table 7.

\section{Daily drying efficiency of the CPTSC}

An experiment was conducted to enhance the efficiency of the parabolic trough solar collector and two air mass flow rate treatments were tested with normal and convective mass air flow rate, $0.6 \mathrm{~kg} \cdot \mathrm{min}^{-1}$ and $1.72 \mathrm{~kg} \cdot \mathrm{min}^{-1}$ under the average temperature of the 
month (January, February and March, 2012). Moreover, the process was replicated three times under the completely randomized design. The result showed that both air mass flow rate and average temperature of the month significantly affected the efficiency of a CPTSC shown in Table 7 . The new model of a CPTSC increased the efficiency from 8 to $25 \%$ with increase in both air mass flow rates and average temperature of the months.

Apple slices were dried in the CPTSC at a normal air mass flow rate $0.6 \mathrm{Kg} . \mathrm{min}^{-1}$ in 14 hours and at a high air mass flow rate $1.72 \mathrm{Kg} \cdot \mathrm{min}^{-1}$ in 12 in the month of January show in Table $1 \& 2$. Because at normal air mass flow rate the CPTSC was low efficiency calculated but a high air mass flow rate the CPTSC was high efficiency obtained. Therefore an apple slices were quick dried at a high efficiency CPTSC which was $1.72 \mathrm{Kg} \cdot \mathrm{min}^{-1}{ }^{1}$. The CPTSC efficiency was obtained $13 \%$ so the apple slices were dried in 12 hours, with a normal air mass flow rate. The efficiency was also obtained $20 \%$ with high flow rate and the apple slices were dried in 10 hours in the month of February 2012. Show in Table 3 \& 4

According to the month of March the CPTSC efficiency were obtained 18\% with a normal air mass flow rate $0.6 \mathrm{Kg} \cdot \mathrm{min}^{-1}$ and the apple slices were dried in 10 hours. Due to the high air mass flow rate the CPTSC efficiency were obtained $25 \%$ which was the highest efficiency of CPTSC, the apple slices were dried in 8 hours. The results show that the CPTSC when the air mass flow rate increased with increasing air mass flow rates is shown in Tables 5 \& 6.

\section{Conclusion}

The technical performance of the CPTSC was found to be satisfactory. A CPTSC efficiency of $8 \%$ and $25 \%$ were predicted for apple in the months of January to March, 2012. Efficiency was $8 \%$ when drying apple with normal air mass flow rate $0.6 \mathrm{~kg} \cdot \mathrm{min}^{-1}$. While efficiency was recorded $13 \%$ with a high air flow rate $1.72 \mathrm{~kg} \cdot \mathrm{min}^{-1}$. The solar radiation was recorded $0.5 \mathrm{cal} . \mathrm{cm}^{-2} \cdot \mathrm{min}^{-1}$ in the month of January, 2012.

Efficiency was $13 \%$ when drying apple with normal air mass flow rate $0.6 \mathrm{~kg} \cdot \mathrm{min}^{-1}$. The solar radiation was recorded $0.7 \mathrm{cal} . \mathrm{cm}^{-2} \cdot \mathrm{min}^{-1}$ in the month of February, 2012. Efficiency was $15 \%$ when drying apple with normal air mass flow rate $0.6 \mathrm{~kg} \cdot \mathrm{min}^{-1}$. The solar radiation was recorded $1 \mathrm{cal} . \mathrm{cm}^{-2} \cdot \mathrm{min}^{-1}$ in the month of March, 2012. The results show that the CPTSC when the air mass flow rate increased with increasing air mass flow rates.

Table:-1 Thermal Performance of CPTSC for drying of apple in the month of January, 2012 with a normal mass air flow rate

\begin{tabular}{|c|c|c|}
\hline Parameter & Unit & Apple \\
\hline Air Mass Flow Rate & Kg.min & 0.6 \\
\hline Average Temperature of the Month & ${ }^{0} \mathrm{C}$ & 25 \\
\hline Drying Time & Hours & 14 \\
\hline Collector Efficiency & $\%$ & 8 \\
\hline Available Solar Intensity & Cal.cm $^{-2} \cdot \mathrm{hr}^{-1}$ & 0.5 \\
\hline
\end{tabular}

Table:-2 Thermal Performance of CPTSC for drying of apple in the month of January, 2012 with a high mass air flow rate

\begin{tabular}{|c|c|c|}
\hline Parameter & Unit & Apple \\
\hline Air Mass Flow Rate & Kg.min & 1.72 \\
\hline Average Temperature of the Month & ${ }^{0} \mathrm{C}$ & 25 \\
\hline Drying Time & Hours & 12 \\
\hline Collector Efficiency & $\%$ & 15 \\
\hline Available Solar Intensity & Cal.cm $^{-2} \cdot \mathrm{hr}^{-1}$ & 0.5 \\
\hline
\end{tabular}


Engineering International, Volume 1, No 1 (2013)

Table:-3 Thermal Performance of Concentrating parabolic trough solar collector for drying of apple in the month of February, 2012 with a normal mass air flow rate

\begin{tabular}{|c|c|c|}
\hline Parameter & Unit & Apple \\
\hline Air Mass Flow Rate & Kg.min & 0.6 \\
\hline Average Temperature of the Month & ${ }^{0} \mathrm{C}$ & 28 \\
\hline Drying Time & Hours & 12 \\
\hline Collector Efficiency & $\%$ & 13 \\
\hline Available Solar Intensity & Cal.cm $^{-2} . \mathrm{hr}^{-1}$ & 0.7 \\
\hline
\end{tabular}

Table:-4 Thermal Performance of Concentrating parabolic trough solar collector for drying of apple in the month of February, 2012 with a high mass air flow rate

\begin{tabular}{|c|c|c|}
\hline Parameter & Unit & Apple \\
\hline Air Mass Flow Rate & Kg.min & 1.72 \\
\hline Average Temperature of the Month & ${ }^{0} \mathrm{C}$ & 28 \\
\hline Drying Time & Hours & 10 \\
\hline Collector Efficiency & $\%$ & 20 \\
\hline Available Solar Intensity & Cal.cm $^{-2} \cdot \mathrm{hr}^{-1}$ & 0.7 \\
\hline
\end{tabular}

Table:-5 Thermal Performance of Concentrating parabolic trough solar collector for drying of apple in the month of March, 2012

\begin{tabular}{|c|c|c|}
\hline Parameter & Unit & Apple \\
\hline Air Mass Flow Rate & Kg.min & 0.6 \\
\hline Average Temperature of the Month & ${ }^{-1} \mathrm{C}$ & 30 \\
\hline Drying Time & Hours & 10 \\
\hline Collector Efficiency & $\%$ & 18 \\
\hline Available Solar Intensity & Cal.cm $^{-2} . \mathrm{hr}^{-1}$ & 1 \\
\hline
\end{tabular}

Table:-6 Thermal Performance of Concentrating parabolic trough solar collector for drying of apple in the month of March, 2012 with a high mass air flow rate

\begin{tabular}{|c|c|c|}
\hline Parameter & Unit & Apple \\
\hline Air Mass Flow Rate & Kg.min & 1.72 \\
\hline Average Temperature of the Month & ${ }^{0} \mathrm{C}$ & 30 \\
\hline Drying Time & Hours & 8 \\
\hline Collector Efficiency & $\%$ & 25 \\
\hline Available Solar Intensity & Cal.cm $^{-2} \cdot \mathrm{hr}^{-1}$ & 0.7 \\
\hline
\end{tabular}

\section{NOMENCLATURES}

$\begin{array}{ll}\text { Aab } & \text { Area of the absorber }\left(\mathrm{m}^{2}\right) \\ \text { Ao } & \text { Outlet ducts of the cross sectional area }\left(\mathrm{m}^{2}\right) \\ A_{p} & \text { Cross sectional area of the product }\left(\mathrm{cm}^{2}\right) \\ A_{r t} & \text { Area of reflecting Trough }\left(\mathrm{m}^{2}\right) \\ \text { Cair } & \text { Specific heat of air }\left(\mathrm{kJ} \cdot \mathrm{kg}^{-1} .{ }^{\circ} \mathrm{C}^{-1}\right) \\ \text { CPTSC } & \text { Concentrating Parabolic Trough Solar Collector } \\ D_{\text {air }} & \text { Density of air at outlet }\left(\mathrm{kg} \cdot \mathrm{cm}^{-3}\right) \\ D_{m} & \text { The dry matter in the product }(\mathrm{g}) \\ D_{r} & \text { The drying rate of the product }\left(\mathrm{g} \mathrm{H2O} . \mathrm{hr}^{-1}\right) \\ D_{t} & \text { Time of drying }(\mathrm{hr}) \\ \text { F.Rair } & \text { The air mass flow rate at outlet }\left(\mathrm{kg} . \mathrm{min}^{-1}\right) \\ \mathrm{f} & \text { Focal length of the trough }(\mathrm{m})\end{array}$




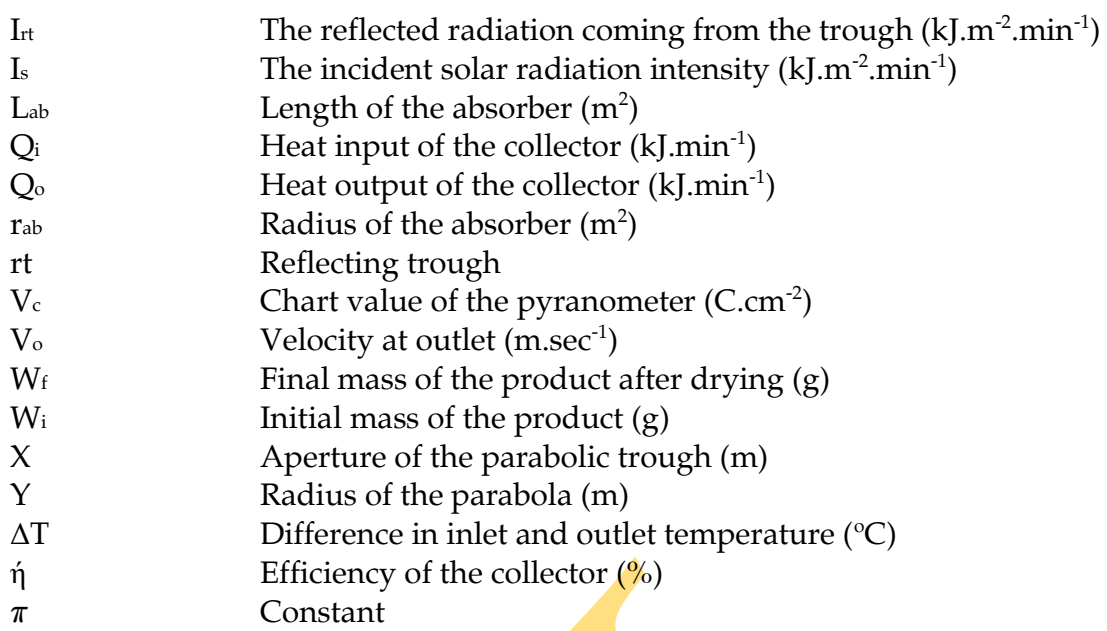

\section{References}

Ahmed A. G. 2011. Design and Construction of a Solar Drying System, a Cylindrical Section and Analysis of the Performance of the Thermal Drying System. Afr. Jr. Agri-Resh vol. 6(2);PP343-351,18.

Aswathanarayana. U., T.Harikrishnan and K.M.T Sahini. 2010. Green Energy. CRC. Press. Taylor and Francise. Balked Books Publishers. India

Balbir Singh M. S and F.Sulaiman. 2009. Electrical and Electronics Engineering, University Teknologi PETRONAS, Bandar Seri Iskandar, 31750 Tronoh, Perak, Malaysia.

Belessiotis.V., and Delyannis.E. 2010. Solar drying. Laboratory of Solar \& other Energy Systems, NSRC "DEMOKRITOS", P.O. box 60228. 153-10. Aghia Paraskevi, Greece.

Christian. N., J. B. Natowitze.. Our Energy Future. A Johan Wiley and Son. INC. Pub. Press.

Dikbasan. T., 2007. Determination of Effective Parameters for Drying of Apples. M.S. Thesis. The Graduate School of Engi. and Sci. Izmir Inst. Tech. Turkey.

Ehiem.J.C., S.V.Irtwange and S.E. Obetta. 2009. Design and Development of an Industrial Fruit and Vegetable Dryer. Dept. Agri. Engi, Uni.Agri. Umudike, Makurdi, Nigeria.

Fuller, R.J., T. Lhendup and L. Aye. 2005. International Technalogies Centre(IDTC). Deptt. Civil and Envi. Engi.Uni. Melbourne Australia.

Henderson and Perry. 1976. Food Processing Engineering. AVI pub. Press. INC.

Matthew G. Green and D.Schwarz. 2001. Solar Drying Technology for Food Preservation. Gate information Service gtz, PO Box 5180, 65726 Eschborn, Germany

Radu D. R. 2010. New Trends in Designing Parabolic trough Solar Concentrators and Heat Storage Concrete Systems in Solar Power Plants. J. Solar Energy. 12(3). 277-287.

Shuang Y., L. Xiao, and Y. R. Li. 2011.Effiect of aperture Position and size on natural convection heat loss of a solar heat- Pipe receiver. Laboratory of low-grade Energy Utilization Technologies and System, Changqing Uni. Ministry of Edu. Changqing 400044, China.

Yadav. S. N. 2011. Agricultural Engineering Fundamentals and Application. Bio Tech Book Publishers, Delhi. India.

\section{Engineering International !!!}

"Speedy publication service, Online archives, Paperless, web-based peer review system, Open access policy, Indexing in world known citation databases, Global circulation, Broad international readership and authorship, Online submission system, Minimum publication charge" 